\title{
POTENSI BUDIDAYA IKAN GURAME DI WANASIGRA CIAMIS MELALUI PEMBUATAN KOLAM BUNDAR
}

\author{
Dedi Nurjamil *1, Asep Saepulloh ${ }^{2}$, Endah Listyasari ${ }^{3}$, Elis Nurhayati ${ }^{3}$ \\ 1,2,3,4 Universitas Siliwangi \\ *e-mail: dedinurjamil@unsil.ac.id ${ }^{1}$,asepsaepulloh@unsil.ac.id \\ ² endah@unsil.ac.id ${ }^{3}{ }_{\text {elisnurhayati@unsil.ac.id }}^{4}$
}

\begin{abstract}
Carp cultivation can be done in the form of a round pond that can be done in the yard. The purpose of this activity is to improve the quality and quantity of carp using a round pond. The implementation of community service is carried out for 3 months, starting from August to October 2021. Activities are carried out starting from planning, namely collaborating with UMKM and the Wanasigra village head, then carrying out the making of a circular pond to evaluation. The conclusion after carrying out the service was that the service activity by making a round fish pond was responded positively by the training participants. Good potential to be developed because it has a positive impact and can be an additional income, and can be applied in their respective homes.
\end{abstract}

Keywords: the potential of carp culture, Round Pond

\begin{abstract}
Abstrak
Pembudidayaan ikan gurame dapat dilakukan dalam bentuk kolam bundar yang dapat dilakukan di halaman rumah. Tujuan kegiatan ini agar dapat meningkatkan kualitas dan kuantitats Ikan Gurame dengan menggunakan kolam bundar. Pelaksanakan pengabdian masyarkat dilaksanakan selama 3 bulan, mulai dari bulan Agustus sampai dengan Oktober 2021. Kegiatan dilaksanakan mulai dari perencanaan, yaitu bekerjasama dengan UMKM dan kepala desa Wanasigra, kemudian pelaksanaan pembuatan kolam bundar sampai dengan evaluasi. Kesimpulan setelah melaksanakan pengabdian adalah kegiatan pengabdian dengan membuat kolam bundar ikan direspon positif oleh peserta pelatihan. Potensi yang baik untuk dikembangkan karena berdampak positif dan dapat menjadi tambahan penghasilan, dan bisa diterapkan di lingkungan rumah masing-masing.
\end{abstract}

Kata kunci: potensi budaya ikan gurame, Kolam Bundar

\section{PENDAHULUAN}

Berbagai alasan mengapa virus ini menjadai pandemi diantaranya penularan yang sangat cepat. Bahkan virus tidak memandang yang tua dan muda, yang tua lebih rentan. Bahkan tingkat kematian untuk golongan muda cukup tinggi. Hal ini seperti dilaporkan There are two reasons that Covid-19 is such a threat. First, it can kill healthy adults in addition to elderly people with existing health problems. The data so far suggest that the virus has a case fatality risk around 1\%; this rate would make it many times more severe than typical seasonal influenza, putting it somewhere between the 1957 influenza pandemic (0.6\%) and the 1918 influenza pandemic (2\%) (Novel, 2020)

Indonesia termasuk negara dengan kasus terinfeksi terbesar di Asia Tenggara. Hal ini menunjukan bahwa virus ini cepat menyebar diantara orang ke orang. Penyebaran tertinggi dikarenakan orang tidak menjaga jarak satu sama lainnya, sehinnga pemerintah mengeluarkan kebijakan untuk memutus mata virus ini melalui peraturan Pembatasan Sosial Berskala Besar (PSBB). PSBB dilakukan agar virus ini tidak menyebar dengan catatan setiap orang melakukan kegiatan di luar rumah jika ada kepentingan yang mendesak dan tidak melakukan berpergian di luar jika memang tidak memiliki kepentingan mendesak.

Ditengah situasi pandemi yang tidak menentu perlu adanya kegiatan pengabdian dosen yang mendorong untuk peningkatan produksi dari UMKM yang ada (Muheramtohadi, 
2017; Nurjanah et al., 2016; Sedyastuti, 2018). Salah satu UMKM yang bergerak di bidang Budidaya Gurame di Ciamis adalah Wanasigra, Sindangkasih Ciamis. Ramphadone Farm merupakan UMKM yang berjalan di Wanasigra Sindangkasih Ciamis yang perlu mendapatkan perhatian agar dapat meningkatkan kualitas Gurame yang dihasilkan.

Dalam perekonomian Indonesia UMKM merupakan kelompok usaha yang memiliki jumlah paling besar dan terbukti tahan terhadap berbagai macam goncangan krisis ekonomi. Kriteria usaha yang termasuk dalam Usaha Mikro Kecil dan Menengah telah diatur dalam payung hukum. Berdasarkan Keputusan Menteri Keuangan Nomor 316/KMK.016/1994 tanggal 27 Juni 1994, usaha kecil didefinisikan sebagai perorangan. Kriteria Usaha Mikro Kecil dan Menengah (UMKM) (Nurjanah et al., 2016; Sukoco et al., 2018)

Penduduk Indonesia yang berjumlah lebih dari 240 juta orang (menurut sensus 2010), ternyata hanya 0,24 persen adalah para wirausaha (interpreneur), atau hanya sekitar 400.000 orang yang berkecimpung dalam dunia usaha atau UMKM. Padahal agar perekonomian Indonesia dapat berkembang lebih cepat diperlukan lebih dari 2 persen dari jumlah penduduk sebagai wirausaha atau berkecimpung dalam UMKM. Singapura, sebuah negara kecil namun mempunyai 7 persen dari jumlah penduduknya merupakan wirausaha dan mempunyai banyak UMKM. Peran Pemerintah melalui Beberapa Program Pemberdayaan UMKM perkembanganUsaha Mikro, Kecil, dan Menengah (UMKM) di Indonesia tidak terlepas dari dukungan perbankan dalam penyaluran kredit kepada UMKM. Setiap tahun kredit kepada UMKM mengalami pertumbuhan dan secara umum pertumbuhannya lebih tinggi dibanding total kredit perbankan. Kredit UMKM adalah kredit kepada debitur usaha mikro, kecil dan menengah yang memenuhi definisi dan kriteria usaha mikro, kecil dan menengah sebagaimana diatur dalam UU No. 20 Tahun 2008 Tentang UMKM. Berdasarkan UU tersebut, UMKM adalah usaha produktif yang memenuhi kriteria usaha dengan batasan tertentu kekayaan bersih dan hasil penjualan tahunan. Keberhasilan Usaha Mikro, Kecil, dan Menengah (UMKM) di Indonesia juga tidak terlepas dari dukungan dan peran pemerintah dalam mendorong penyaluran kredit kepada UMKM (Muheramtohadi, 2017).

Melihat pentingnya pemberdayaan UMKM maka tim pengabdian Universitas Siliwangi akan melakukan kegiatan pengabdian di Wanasigra Sindangkasih Ciamis dengan basis peningkatan kualitas dan kuantitas UMKM budidaya Gurame. Pengabdian tersebut akan diimplementasikan dalam kegiatan Potensi Budidaya Ikan Gurame Di Wanasigra Ciamis Melalui Peningkatan Dan Pemberdayaan Kinerja UMKM Sebagai Bentuk Ketahanan Pangan Di Masa Pandem Covid 19

\section{METODE}

Mitra yang menjadi bagian utama dalam kegiatan pengabdian masyarakat ini yaitu masyarakat di Wanasigra, mengalami permasalahan diantaranya:

1. Peningkatan kualitas ikan gurama di desa Wanasigra Sindangkasih Ciamis masih perlu ditingkatkan

2. Belum terlaksananya pelatihan peningkatan kualitas gurame di Wanasigra Sindangkasih Ciamis

3. Pemasaran ikan gurame di Wanasigra Sindangkasih Ciamis perlu mendapatkan pelatihan sehingga volume penjualan lebih meningkat

Pengabdian rencana dilaksanakan di Wanasigra Sindangkasih Ciamis yang terdiri dari masyarakat dan kelompok budidaya ikan gurame dengan target sebagai berikut: 
1. Meningkatkan kualitas pembudidayaan ikan gurame di Wanasigra Sindangkasih Ciamis

2. Meningkatnya kuantitasi penjualan gurame di Wanasigra Sindangkasih Ciamis

Pelaksanaan kegiatan pengabdian ini mengikuti aktivitas perencanaan, pelaksanaan dan evaluasi. Uraian dari langkah-langkahnya adalah sebagai berikut:

1. Perencanaan

Kegaitan perencanaan dimulai dari:

a. Melakukan kordinasi dengan LPMP PMP Universitas Siliwangi dan pihak Desa Wanasigra Sindangkasih Kabupaten Ciamis

b. Melakukan koordinasi dengan UMKM di daetah Pokdakan Neureus Desa Wanasigra

c. Sosialisasi bahwa akan dilaksanaan pengabdian di lokasi mengenai budidaya ikan gurame di Pokdakan Neureus Desa Wanasigra

d. Penyusunan kegiatan pengabdian dengan kepala desan dan kepala Pokdakan Neureus Desa Wanasigra

2. Tindakan

Kegiatan tindakan dilaksanakan dengan memberikan edukasi pada masyarakat di desa P Desa Wanasigra Sindangkasih Kabupaten Ciamis mengenai budidaya gurame agar kualitasnya meningkat, langkah-langkah yang dilakukan dapat di perjelas sebagai berikut:

a. Mitra memilih orang untuk dilakukan pelatihan

b. Mitra diberikan bantuan berupa alat budaya ikan gurame

c. Mitra akan dilatih pembudidayaan ikan gurame

3. Evaluasi

Evaluasi dilaksanakan secara bersama-sama antara tim pengabdian dan mitra dalam rangka melakukan perbaikan kegiatan selanjutnya.

\section{HASIL DAN PEMBAHASAN}

Pelaksanaan kegiatan pengabdian ini dilaksanakan selama 3 bulan mulai dari bulan Agusuts 2021 sampai dengan Oktober 2021. Minggu pertama agustus diskusi dengan tim dan kepala desa serta ketua UMKM UMKM RAMPHADONE FARM yang diketuai oleh Mohamad Thibyan. Setelah disepakati maka dilakukan pembuatan dua kolam ikan Gurame bendar dengan ukuran diameter $3 \mathrm{~m}$, seperti tampak pada gambar dibawah ini: 


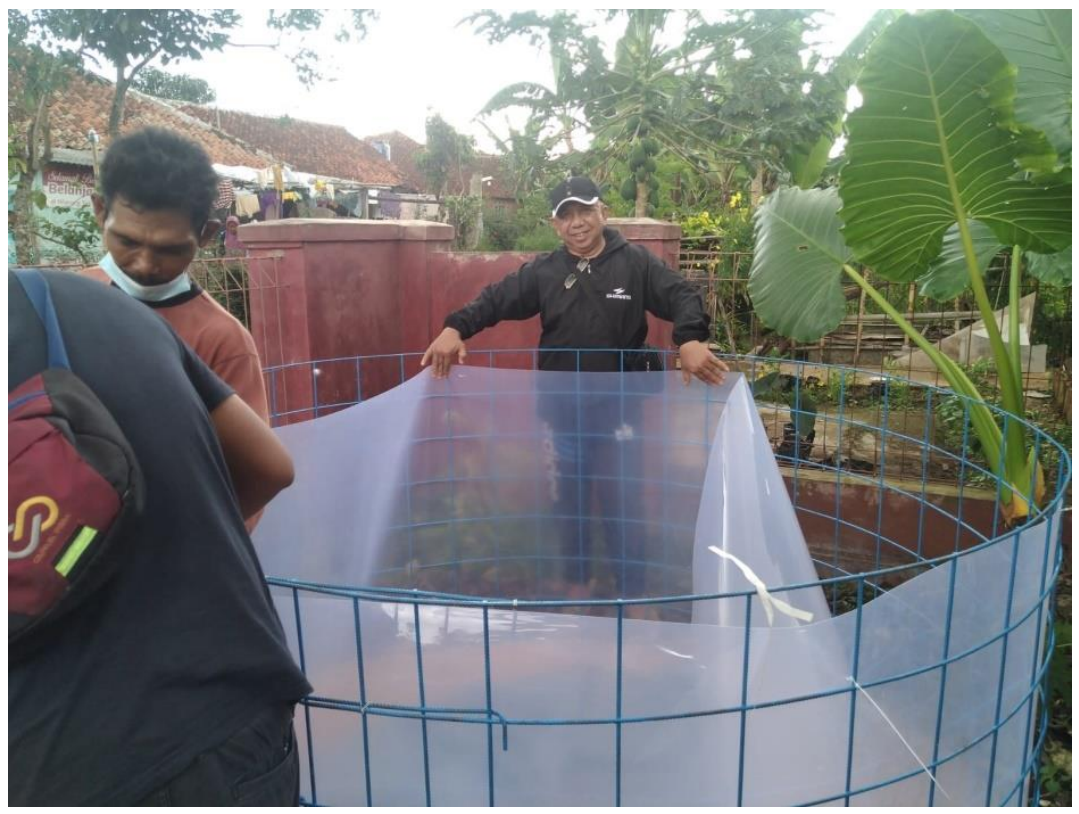

Gambar 1. Pembuatan Kolam Bundar

Pembuatan kolam bundar menggunakan jaring besi yang sudah disiapkan dan kemudian dinding-dingingnya dilengka plastik tebal agar air tidak ada yang rembes. Kemudian dasar kolam menggunakan

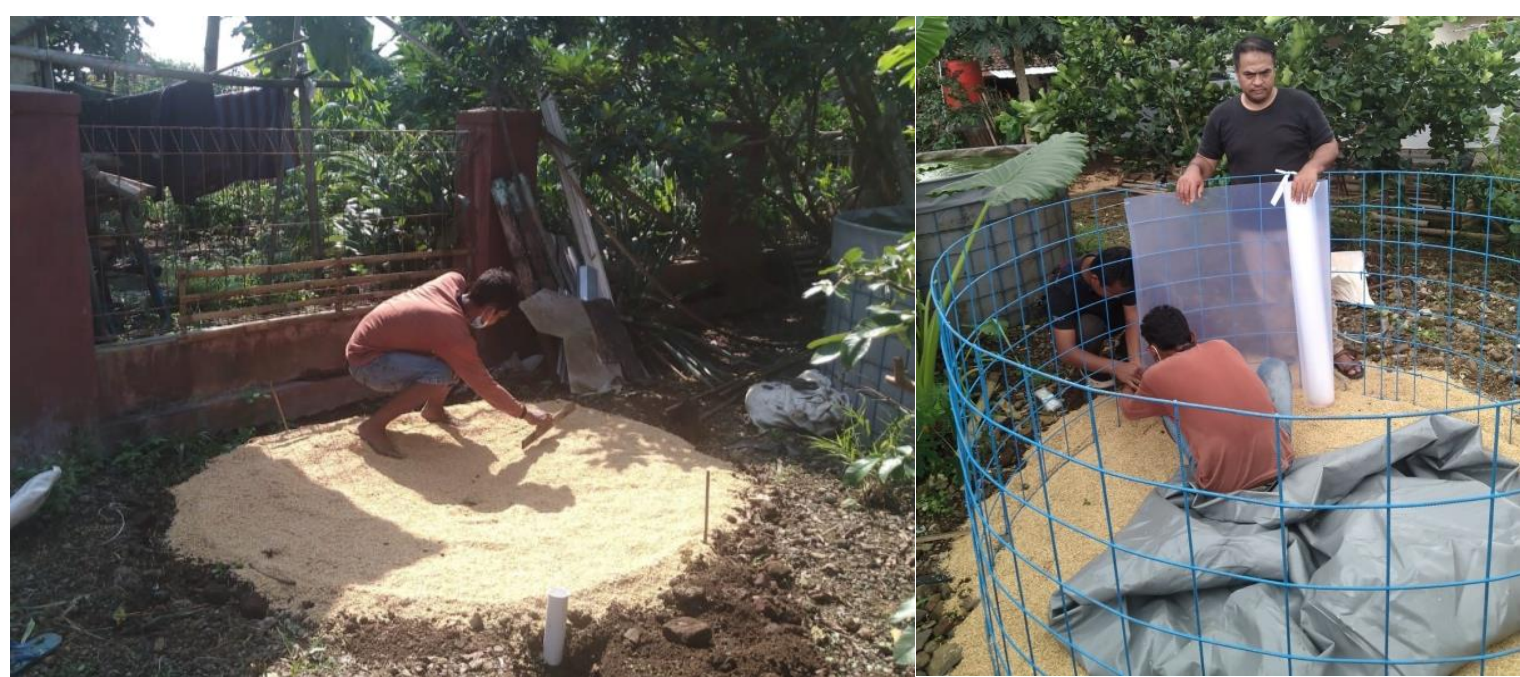

Gambar 1. Pembuatan Dasar Kolam Bundar Ikan Gurame

Setelah memilih tempat yang akan dijadikan pembuatan kolam bundar, kemudian alas dari kolam memakai gabah. Hal ini agar kotoran ikan dapat tersimpan di bawah, sehingga nanti pembuangan kotoran dapat dengan mudah dengan cara mengeluarkan air dari bawah. Kemudian setelah itu di buat kolam bundar yang sudah disesuaikan dengan foto sebagai berikut: 


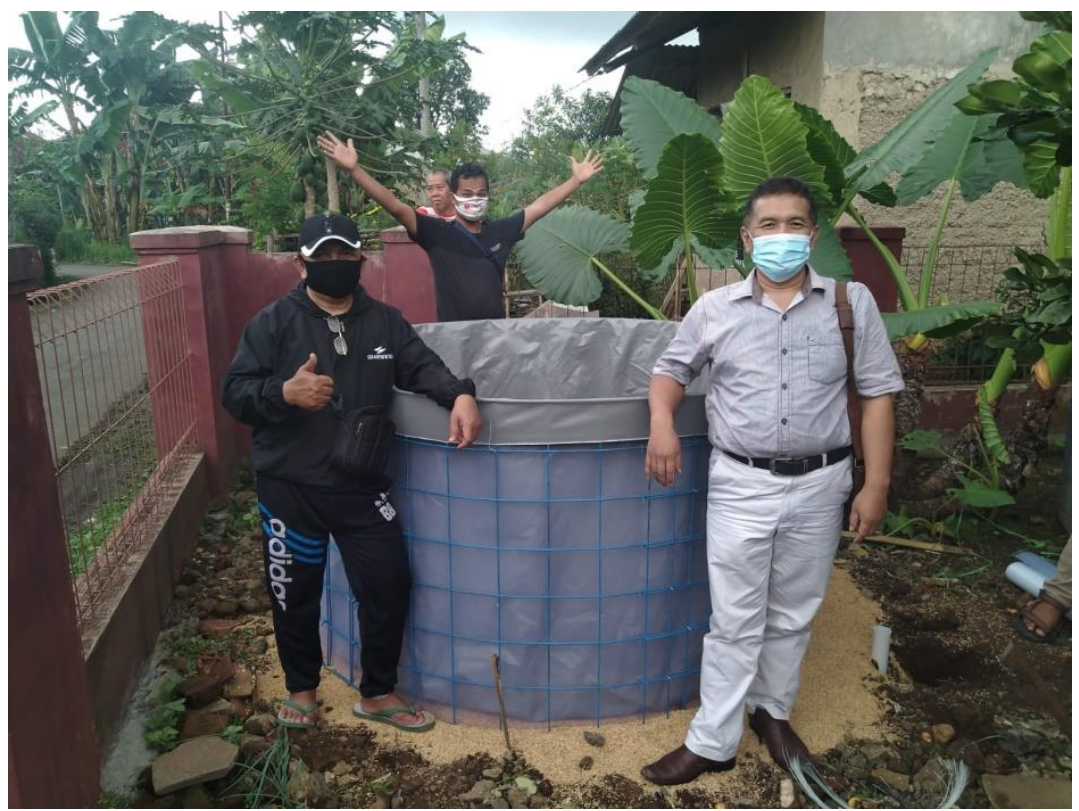

Gambar 2. Pembuatan Kolam Bundar Untuk Ikan Gurame

Setelah kolam siap digunakan kemudian kolam di isi air dan disisikan sedikit diatasnya. Gambar nya nampak sebagai berikut

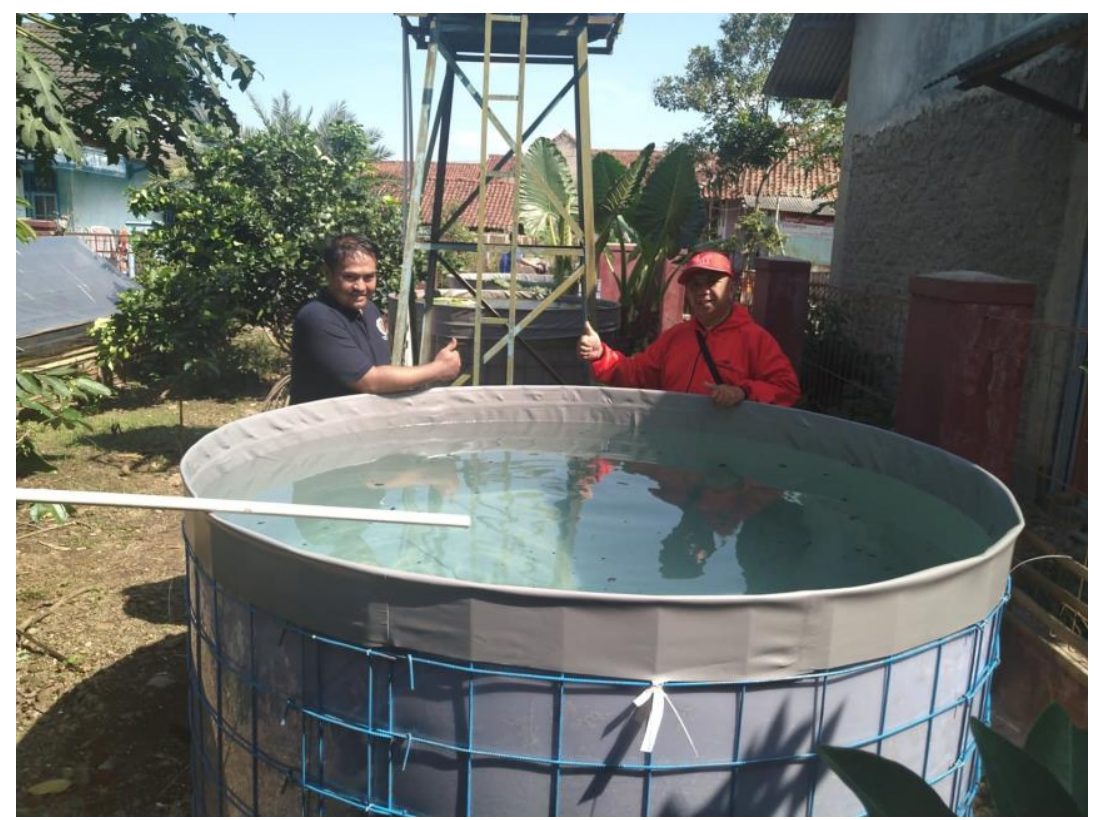

Gambar 3. Pengisian Air di Kolam Bundar

Setelah proses pembuatakolam bifolk dilakukan pengisian air sumur didiamkan selama 2 hari minimal maksimal selama satu minggu. Kemudian Dimasukan garam sebanyak $2 \mathrm{~kg}$ per meter kubik, mematikan bakteri di air Memasukan kapur dolomaite perikanan 200-250 gr per meter kibik untuk menentralkan $\mathrm{Ph}$ Air sehingga Ph air cocok untuk ikan. Tampak gambarnya sebagai berikut: 


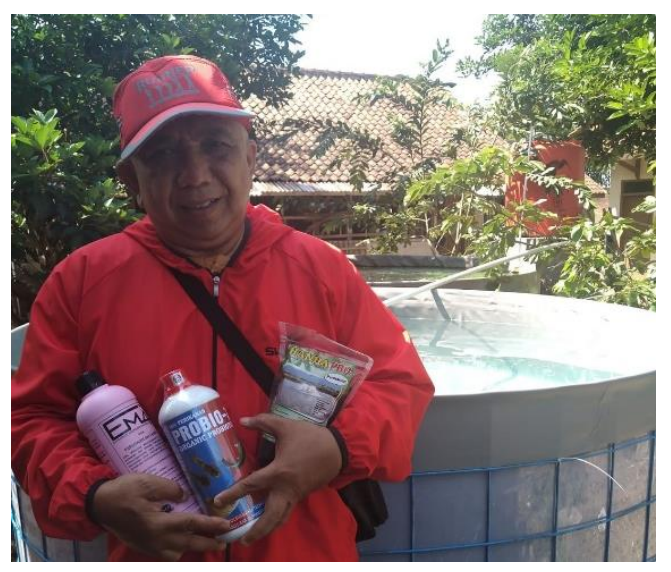

Gambar 4. Penaburan Obat Agar Bakteri Mati dan Ph Air Cocok Untuk Ikan Gurame

Kolam dengan diameter bisa dimasukan ikan sebanyak 300 ekor dengan ukuran silet kecil, dengan pakan $10 \%$ dari bobot ikan pada saat satu kali memberikan pakan. Kolam diproyeksikan di gunakan pertama sampai 4 bulan dan berubah dari ukuran silet menjadi ukuran pahpir, dengan tingkat mortalitasi adalah $10 \%$ setiap kenaikan tingkatan ikan. Jika cuaca alam mendukung selama 4 bulan harga dasar 2000 per ikan gurame dapa dijual dengan harga 4000 per ekor.

Proyeksi keuntungan setelah mortalitasi ikan sebanyak $10 \%$ setiap peningkatan bentuk ikan membuat keuntungan menjadi lebih tinggi. Selama tidak terjadi cuaca yang ekstrim maka ikan akan aman dari bakteri sehingga tidak menimbulkan kematian yang banyak terhadap ikan.

Masyarakat merespon positif kegiatan yang dilaksanakan oleh tim Pengabdian Masyarakat yang dilaksanakan oleh UNSIL. Dari 20 peserta yang ikut pelatihan 90\% merespon positif kegiatan yang dilaksanakan dan berharap ada kegiatan yang berkelanjutan dalam melaksanakan kegiatan sehingga bisa ada penghasilan tambahan dalam situasi pandemic Covid-19. Kepala desa wanasigra mengapresiasi kegiatan ini dan bisa membantu masyarakat sebagai bentuk usaha sampingan di tengah wabah Covid-19, kepala desa, ketua UMKM dan masyarakat berharap agar kegiatan seperti ini dapat dilanjutkan secra terus menerus untuk membantu meningkatkan pendapatan masyarakat Desa Wanasigra, Sindangkasih Kabupaten Ciamis.

\section{KESIMPULAN}

Kesimpulan setelah melaksanakan pengabdian adalah kegiatan pengabdian dengan membuat kolam bundar ikan direspon positif oleh peserta pelatihan. Potensi yang baik untuk dikembangkan karena berdampak positif dan dapat menjadi tambahan penghasilan, dan bisa diterapkan di lingkungan rumah masing-masing.

\section{UCAPAN TERIMA KASIH (Bila Perlu)}

Ucapan terimakasih kepada Rektor Universitas Siliwangi dan Ketua LPPM Universitas Siliwangi yang telah mendukung dana serta memotivasi dalam melaksanakan kegiatan pengabdian. 


\section{DAFTAR PUSTAKA}

Isbandi. (2005). Penyuluhan untuk Pembaharuan Perilaku. Badan Penerbit Universitas Diponegoro, Semarang

Muheramtohadi, S. (2017). Peran Lembaga Keuangan Syariah dalam Pemberdayaan UMKM di Indonesia. MUQTASID Jurnal Ekonomi Dan Perbankan Syariah, 8(1), 95. https://doi.org/10.18326/muqtasid.v8i1.95-113

Nurjanah, N., Wirman, W., \& Yazid, T. P. (2016). Implementasi Program Coorporate Social Responsibility (Csr) Dalam Meningkatkan Pemberdayaan Masyarakat Provinsi Riau. Jurnal IImu Komunikasi, 197-211. https://jkms.ejournal.unri.ac.id/index.php/JKMS/article/download/4750/4489

Novel, C. P. E. R. E. (2020). The epidemiological characteristics of an outbreak of 2019 novel coronavirus diseases (COVID-19) in China. Zhonghua liu xing bing xue za zhi= Zhonghua liuxingbingxue zazhi, 41(2), 145.

Setiana L. (2005). Teknik Penyuluhan \& Pemberdayaan Masyarakat. Jakarta: Ghalia Indonesia

Sedyastuti, K. (2018). Analisis Pemberdayaan UMKM Dan Peningkatan Daya Saing Dalam Kancah Pasar Global. INOBIS: Jurnal Inovasi Bisnis Dan Manajemen Indonesia, 2(1), 117-127. https://doi.org/10.31842/jurnal-inobis.v2i1.65

Setyawan, D., Rohman, F., \& Sutomo, H. (2016). Kajian etnozoologi masyarakat Desa Hadiwaarno Kabupaten Pacitan dalam konservasi penyu sebagai bahan penyusunan booklet penyuluhan masyarakat. JPBI (Jurnal Pendidikan Biologi Indonesia), 1(3).

Sukoco, A., Setiawan, M. I., Mudjanarko, S. W., Nasihien, R. D., Suyono, J., Sudapet, I. N., \& Alie, M. (2018). Alat Pembuat Pakan Ikan Dengan Sumber Listrik Tenaga Surya (Solar Powered Fish Feeding Machine), Mendukung Peningkatan Pendapatan UMKM Dan Produksi Pakan Ikan Daerah. Janaka, Jurnal Pengabdian Masyarakat, 1(1), 15-29.

Soehoet, H. (2003). Media Komunikasi. Jakarta: Penerbit Yayasan Kampus Tercinta, IISIP World Health Organization. (2020). WHO Virtual press conference on COVID-19. World Health Organization. (2020). Coronavirus disease (COVID-2019) situation reports. 